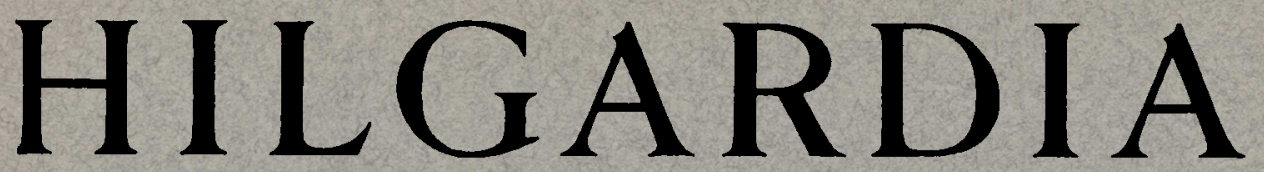

A Journal of Agricultural Science Published by the California Agricultural Experiment Station

CONTENTS

FACTORS INFLUENCING THE EFFECTIVENESS OF SODIUM CHLORATE AS A HERBICIDE

\author{
A. S. CRAFTS
}

THE TOXICITY OF SODIUM ARSENITE AND SODIUM CHLORATE IN FOUR CALIFORNIA SOILS

A. S. CRAFTS 


\title{
$\begin{array}{lllllllll}H & \text { I } & \text { L } & G & A & R & D & \text { I } & A\end{array}$
}

A Journal of Agricultural Science Published by

the California Agricultural Experiment Station

VoL. 9

JULY, 1935

No. 9

\section{FACTORS INFLUENCING THE EFFECTIVENESS OF SODIUM CHLORATE AS A HERBICIDE ${ }^{1}$}

\author{
A. S. CRAFTS ${ }^{2}$
}

\section{INTRODUCTION}

WITH THE RECOGNITION that the principal action of sodium chlorate on deep-rooted perennial weeds takes place throngh the soil ${ }^{(1,9,10,11)}$ comes a clearer understanding of the importance of those factors that influence the absorption of this material from the soil. The newer concepts of chlorate action ${ }^{(9,10,11)}$ promise a distinct advance in the technical use of this chemical, especially in those regions where summer rains do not occur.

In regions of frequent summer rains, freezing winters, and relatively shallow soils, the chlorates have been notably effective as herbicides. In the western states, however, chlorates have given erratic results and in many instances have been practically worthless when applied in early summer as recommended in the more humid states.

Most of the deep-rooted perennials of the West blossom in April, May, or June, and chlorate sprays applied during these months lie in contact with organic matter, exposed to the decomposing action of the ultraviolet rays of the sun, from four to eight months before being leached into the soil. Though killing of the tops may be rapid and complete when the applications are made according to recommended methods, root killing is usually slight or absent; and by autumn, decomposition of the chlorate has greatly reduced its concentration. Winter rains are so variable in amount and distribution that the depth of leaching is uncertain. Root systems of the weeds may extend to depths of 10 to 20 feet or more and are seldom injured by freezing temperatures except in the extreme Northwest or at high elevations. The weeds, there-

1 Received for publication December 18, 1934.

2 Assistant Botanist in the Experiment Station. 
fore, have every advantage; and dosages of 2 to 6 pounds. of sodium chlorate per square rod applied in the early summer often prove almost totally ineffective.

Though the field operator need not understand the principles involved in the toxic action of sodium chlorate, the experimenter must recognize fully the importance of the various factors influencing its effectiveness and must take the utmost advantage of all naturally occurring agencies to make the methods that he recommends as complete and efficient as possible.

In California in plot tests and in the field it is relatively easy to differentiate between the effects of chlorate applied through the soil and through the plant. As experiments have shown, roots may be killed by the action of chlorate applied through the plant; but this type of response, as a basis for weed-killing practice, is less reliable than treatment through the soil. Since both these effects are often encountered in the field and cannot easily be separated in regions of summer rainfall, the following results obtained in California may serve to establish their relative importance.

\section{EXPERIMENTAL RESULTS}

\section{Greenhouse Tests on the Effects of Foliage and Soll Applications of ChLorate}

The first experiments are reported simply to confirm the results obtained by workers in New York ${ }^{(1,11)}$ and Iowa. ${ }^{(9,10)}$ They were designed to differentiate, under partially controlled conditions in the greenhouse, between the effects of chlorate applied to the tops of plants by spraying, and those of soil application.

The plants used were morning-glory (Convolvulus arvensis L.), growing in soil tubes 4 inches in diameter and 3 feet deep; and Russian knapweed (Centaurea repens L.) and hoary cress (Lepidium draba L.), growing in 12-inch earthenware pots. The soil was Yolo clay loam with a field capacity of approximately 30 per cent and a permanent wilting percentage of 14 .

The treatments were: (1) Spraying of the foliage with 25 ce of 10 per cent $\mathrm{NaClO}_{3}$ solution after having covered the soil carefully with dry sphagnum moss. The plants were in blossom and had had normal watering. Applications were made in the daytime. The moss and dead foliage were later removed so that no chlorate solution reached the soil. (2) Application to the soil of 250 ce of 1 per cent $\mathrm{NaClO}_{3}$ solution, care being taken to avoid wetting the tops. A normal irrigation followed, and subsequent waterings were given when required by the untreated 


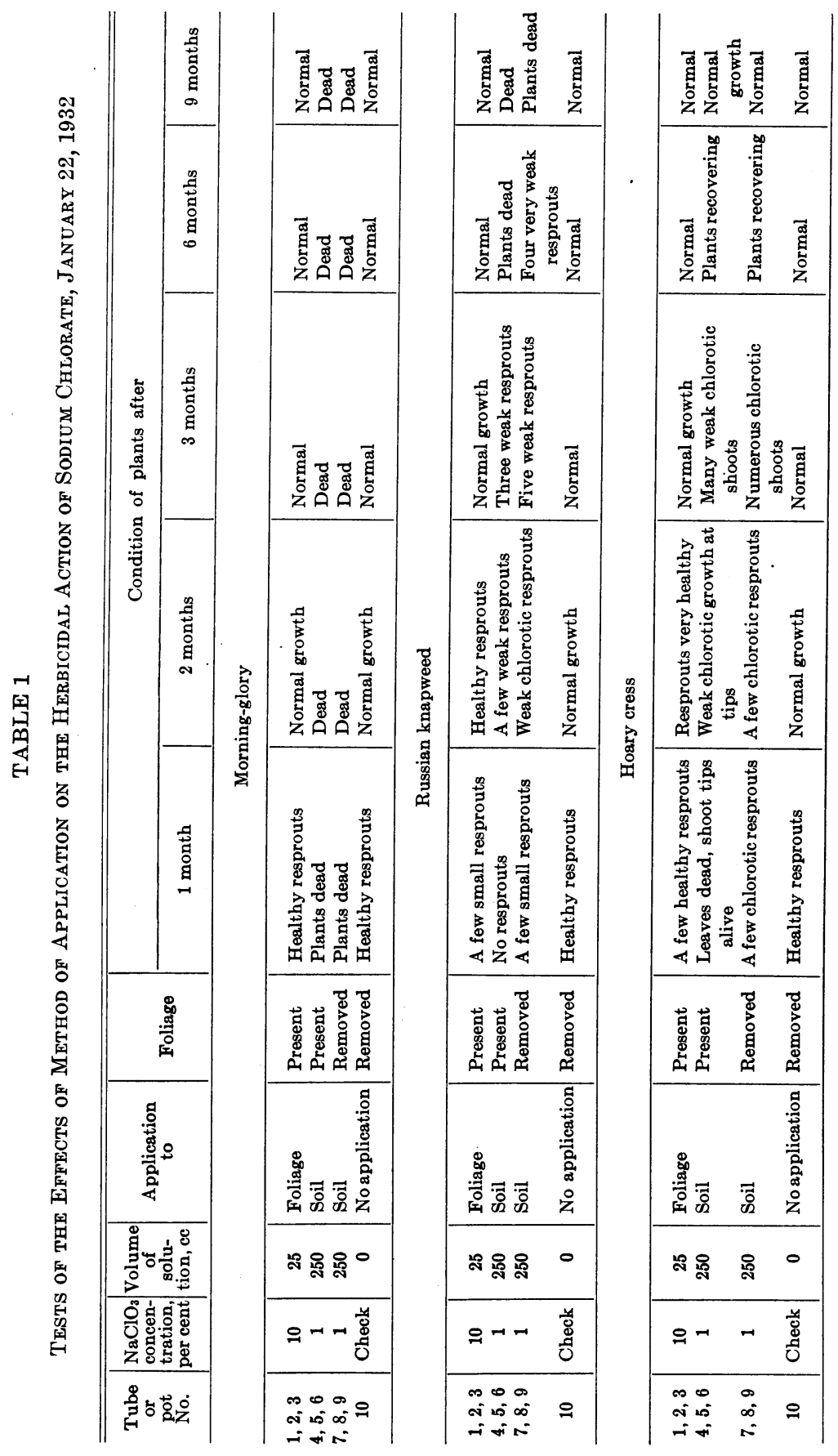


checks. (3) Applications similar to treatment 2 after removal of all top growth. Irrigations followed as in treatment 2. The results appear in table 1.

All tests were run in triplicate. There were untreated checks (not shown in the table) and checks with tops removed but with no application of chlorate.

Evidently spraying the foliage under the conditions of this experiment had an effect differing in no essential feature from simple removal by cutting. Though resprouting was slightly delayed and the shoots were somewhat chlorotic, they soon assumed a normal appearance and growth, with no sign of permanent injury to the roots.

Applying a like amount of chlorate to the soil resulted in the ultimate death of all morning-glory and Russian knapweed plants. Removing the tops hindered absorption, as did lowering the transpiration by other means in the Iowa experiments; ${ }^{(10)}$ Russian knapweed was killed somewhat more slowly than morning-glory under these conditions. Soil application caused severe injury to the hoary cress plants but did not kill them : as the chlorate disintegrated with rising greenhouse temperatures, ${ }^{(10)}$ the plants slowly recovered. A difference in susceptibility of different species was clearly shown. ${ }^{(5,6,10)}$

This same experiment was conducted a second time with morningglory plants with identical results. Evidently when plants in the blossoming stage, amply supplied with moisture, are sprayed with a chlorate solution during the day, there is practically no translocation of the chemical within the plant and no permanent injury.

\section{Plot Tests : Relation of Time of Application and Rainfall to EFFectiveness of Chlorate}

Since chlorate is effective when applied through the soil, it would seem logical in California to delay spraying until the winter rains begin. It would also follow that the ultimate location of the herbicide within a given soil would depend upon the amount and distribution of the rainfall and would be reflected by visible injury to roots growing in the soil.

Series of square-rod ${ }^{3}$ plots have been treated during the past three winter seasons in a study of the effects of rainfall on movement of chlorate in the soil. In each case, unless otherwise noted, treatment consisted of simply spraying the plot with a solution containing 3 pounds of sodium chlorate dissolved in 3 gallons of water. Before the frosts, applieations were made to the living foliage and soil, the plots being left undisturbed. Later applications were made on the dead foliage and soil. An even distribution of the chemical on the square-rod area was at-

3 All plots reported in this paper were one square rod in area. 
tempted regardless of distribution of the weeds. The principal weed was morning-glory, and the treated plots were all heavily infested. The soil was Yolo loam. Table 2 gives the results of these experiments for the season 1931-32.

These plots show the influence of the various factors affecting chlorate sprays. The first three applications were subject to considerable decomposition as well as to leaching by the total seasonal rains. The

TABLE 2

The Relation of Rainfall to Resprouting of Morning-Glory Treated with SODIUM CHLORATE, 1931-32

\begin{tabular}{|c|c|c|c|c|c|c|c|}
\hline \multirow{2}{*}{$\begin{array}{l}\text { Plot } \\
\text { No. }\end{array}$} & \multirow{2}{*}{ Date of application } & \multirow{2}{*}{$\begin{array}{c}\text { Condition } \\
\text { of } \\
\text { foliage }\end{array}$} & \multicolumn{2}{|c|}{ Rainfall, in inches } & \multicolumn{3}{|c|}{$\begin{array}{l}\text { Estimated per cent resprout- } \\
\text { ing,* } 1932\end{array}$} \\
\hline & & & Before & After & May 17 & June 21 & Nov. 21 \\
\hline 1 & Aug. $21,1931 \ldots$ & Alive $\ldots . . . .$. & 0 & 15.08 & 40 & 60 & 75 \\
\hline 2 & Sept. $15,1931 \ldots \ldots \ldots \ldots \ldots$. & Alive $\ldots . . . . .$. & 0 & 15.08 & 45 & 70 & 75 \\
\hline 3 & Oct. $\quad 15,1931 \ldots \ldots$. & Alive........... & 0 & 15.08 & 75 & 70 & 60 \\
\hline 4 & Nov. $15,1931 \ldots$. & Alive $\ldots \ldots \ldots . . . . .$. & 1.49 & 13.59 & 80 & 85 & 40 \\
\hline 5 & Dec. 16,1931 & Dead $\ldots . . . . . . . .$. & 2.53 & 12.55 & 40 & 30 & 5 \\
\hline 6 & Jan. $\quad 20,1932 \ldots \ldots \ldots \ldots \ldots \ldots$ & Dead............. & 10.47 & 4.61 & 1 & 2 & 25 \\
\hline 7 & Feb. $\quad 17,1932$ & Dead............... & 12.39 & 2.69 & 50 & 50 & 60 \\
\hline
\end{tabular}

* The values given here and in succeeding tables for percentage of resprouting are visual estimates. not actual counts. One morning-glory plant may send up several hundred weak shoots from one injured root, while another may send up one or two relatively strong ones. In such cases a count means little. All estimates given in this paper were made by the writer, who considered not only the numbers of shoots but also their vigor. The values given, therefore, are more truly a measure of the effectiveness of the treatment than a count could possibly be.

chemical on the November plot was also subject to excessive leaching, but the toxic effects of the chlorate increased considerably during the season of 1932. The chemical was carried to a depth of about 5 feet in the December plot; and although it was dilute during the fore part of 1932, as the soil moisture decreased it reached a lethal concentration within the plants, so that very few survived the summer. In 1933 this plot and several others sprayed at the same time were devoid of morning-glory. The January plot received much less rainfall, and the roots were killed rather uniformly to a depth of 3 feet. They resprouted from this level, however, and made considerable growth by fall. Throughout 1933 they continued to improve; and in 1934 the plot was nearly normal. Roots in the February plots were killed only to a depth of 1 foot; and resprouting was vigorous, improving with time.

The results of plot tests of the following two seasons appear in tables 3 and 4 . Since other than edaphic factors enter the problem where applications are made during late summer and fall, only the winter plots are included.

As rainfall was deficient during both these winters, only the earlysprayed plots showed satisfactory results. The erratic nature of rainfall 
distribution is well illustrated in these tables. In all three of these winters, most of the rains occurred during a few heavy storms in December and January; and subsequent precipitation was insufficient to provide

TABLE 3

The Relation of Rainfall to Resprouting of Morning-Glory Treated with SODIUM CHLORATE, 1932-33

\begin{tabular}{|c|c|c|c|c|c|c|c|}
\hline \multirow{2}{*}{$\begin{array}{l}\text { Plot } \\
\text { No. }\end{array}$} & \multirow{2}{*}{ Date of application } & \multirow{2}{*}{$\begin{array}{c}\text { Condition } \\
\text { of } \\
\text { foliage }\end{array}$} & \multicolumn{2}{|c|}{ Rainfall, in inches } & \multicolumn{3}{|c|}{$\begin{array}{l}\text { Estimated per cent resprout- } \\
\text { ing, } 1933\end{array}$} \\
\hline & & & Before & After & May 31 & June 30 & Nov. 17 \\
\hline 1 & Dec. $15,1932 \ldots$ & Alive $\ldots \ldots \ldots . . . . . .$. & 0.39 & 9.17 & 1 & 1 & 1 \\
\hline 2 & Dec. $\quad 20,1932$ & Alive $\ldots \ldots \ldots . . . . . .$. & 1.51 & 8.05 & 7 & 7 & 5 \\
\hline 3 & Dec. $\quad 20,1932$ & Alive................ & 1.51 & 8.05 & 2 & 2 & 2 \\
\hline 4 & Dec. $\quad 30,1932 \ldots$ & Alive $\ldots \ldots \ldots . . . . . .$. & 2.56 & 7.00 & 15 & 15 & 10 \\
\hline 5 & Jan. $16,1933 \ldots \ldots \ldots \ldots$ & Dead................ & 2.66 & 6.90 & 10 & 10 & 10 \\
\hline 6 & Jan. $\quad 30,1933 \ldots \ldots \ldots \ldots \ldots$ & Dead................. & 6.33 & 3.23 & 40 & 75 & 75 \\
\hline 7 & Feb. $\quad 15,1933$ & Dead................. & 6.98 & 2.58 & 20 & 60 & 95 \\
\hline 8 & $1,1933 \ldots \ldots \ldots \ldots$ & Dead.................. & 6.99 & 2.57 & 90 & 95 & 90 \\
\hline 9 & $1,1933 \ldots \ldots \ldots \ldots \ldots$ & Dead ............... & 6.99 & 2.57 & 45 & 70 & 90 \\
\hline 10 & Mar. $15,1933 \ldots \ldots \ldots \ldots$ & Dead................ & 7.69 & 1.87 & 35 & 80 & 90 \\
\hline 11 & April $1,1933 \ldots \ldots$ & Alive $\ldots \ldots \ldots . . . . . .$. & 8.94 & 0.62 & 95 & 95 & 95 \\
\hline
\end{tabular}

TABLE 4

'i'he Rela'iton of Rainfall to Resprouting of Morning-Glory Treated with Sodium Chlorate, 1933-34

\begin{tabular}{|c|c|c|c|c|c|c|c|}
\hline \multirow{2}{*}{$\begin{array}{l}\text { Plot } \\
\text { No. }\end{array}$} & \multirow{2}{*}{ Date of application } & \multirow{2}{*}{$\begin{array}{l}\text { Condition of } \\
\text { foliage }\end{array}$} & \multicolumn{2}{|c|}{ Rainfall, in inches } & \multicolumn{3}{|c|}{$\begin{array}{l}\text { Estimated per cent resprout- } \\
\text { ing, } 1934\end{array}$} \\
\hline & & & Before & After & April 3 & May 10 & July 16 \\
\hline 1 & Dec. $\quad 10,1933 \ldots \ldots$ & Alive & 1.77 & 9.36 & 15 & 10 & 15 \\
\hline 2 & Dec. $10,1933 \ldots$ & Hoed off. & 1.77 & 9.36 & 5 & 7 & 10 \\
\hline 3 & Dec. $10,1933 \ldots$ & Spaded under*.. & 1.77 & 9.36 & 1 & 2 & 5 \\
\hline 4 & Dec. $\quad 20,1933$ & Alive & 4.39 & 6.74 & 10 & 5 & 5 \\
\hline 5 & Jan. $\quad 1,1934 \ldots \ldots \ldots \ldots$ & 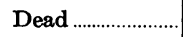 & 5.59 & 5.54 & 15 & 75 & 90 \\
\hline 6 & Jan. $\quad 1,1934 \ldots$ & Spaded*..... & 5.59 & 5.54 & 7 & 40 & 75 \\
\hline 7 & Jan. $\quad 10,1934 \ldots$ & 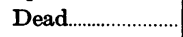 & 6.61 & 4.52 & 20 & 75 & 100 \\
\hline 8 & Jan. $\quad 20,1934 \ldots$ & Dead.... & 6.77 & 4.36 & 20 & 75 & 100 \\
\hline 9 & Feb. $\quad 1,1934 \ldots$ & Dead............ & 6.78 & 4.35 & 7 & 40 & 100 \\
\hline 10 & Feb. $\quad 1,1934 \ldots$ & Spaded*.................. & 6.78 & 4.35 & 5 & 15 & 75 \\
\hline 11 & Feb. $\quad 10,1934 \ldots$ & 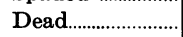 & 7.44 & 3.69 & 35 & 75 & 100 \\
\hline 12 & Feb. $20,1394 \ldots$ & 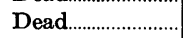 & 8.67 & 2.46 & 35 & 100 & 100 \\
\hline 13 & March $1,1934 \ldots \ldots \ldots \ldots$ & . & 9.99 & 1.14 & 50 & 100 & 100 \\
\hline
\end{tabular}

* Plots 3, 6, and 10 received 2 pounds $\mathrm{NaClO}_{3}$, were spaded and then received 1 pound $\mathrm{NaClO}_{3}$.

proper penetration of the chlorate. The added effect of spading under a part of the chlorate is evident in plots 3, 6, and 10 of table 4; and in years of deficient rainfall this procedure might prove effective, a plow being used in field applications. As shown by the results on these plots, distribution of the chlorate in the soil is a factor of vital importance in the use of this chemical. 


\section{Relation of Applied Water to Depth of Penetration of Chlorate}

In the hope of finding a method by which to control more accurately the penetration of chlorate in the soil, several plots were prepared and treated in May, 1932. First they were hoed to remove the top growth, which was profuse and in the early stages of blossoming. Then, having been diked, four of the plots were irrigated, sprayed early the following

TABLE 5

The Effects of Sodium. Chlorate Application Followed by Irrigation upon Hoed Morning-Glory Plots

\begin{tabular}{|c|c|c|c|c|c|c|c|c|c|}
\hline \multirow[b]{2}{*}{$\begin{array}{l}\text { Plot } \\
\text { No. }\end{array}$} & \multirow[b]{2}{*}{ First irrigation } & \multirow[b]{2}{*}{$\mathrm{NaClO}_{3}$ spray } & \multicolumn{2}{|c|}{ Second irrigation } & \multicolumn{5}{|c|}{ Estimated per cent resprouting } \\
\hline & & & Date & $\begin{array}{l}\text { Am't, } \\
\text { inches }\end{array}$ & $\underset{1932}{\text { Aug. 11 }}$ & ${ }_{1932}^{\text {Nov. 21, }}$ & $\underset{1933}{\text { May 31, }}$ & $\underset{1933}{\text { June } 30}$ & ${ }_{1933}^{\text {Nov. } 17,}$ \\
\hline 1 & \multirow{4}{*}{ May 24,4 in. } & \multirow{4}{*}{ May 25, a.m. } & \multirow{4}{*}{ May 25} & 2 & 90 & 20 & 10 & 10 & 50 \\
\hline 2 & & & & 4 & 15 & 5 & 1 & 1 & 10 \\
\hline 3 & & & & 6 & 30 & 10 & 5 & 10 & 15 \\
\hline 4 & & & & 8 & 100 & 25 & 30 & 30 & 50 \\
\hline 5 & \multirow{4}{*}{ 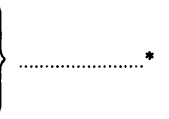 } & \multirow{4}{*}{ May 26, a.m. } & \multirow{4}{*}{ May 26} & 2 & 50 & 25 & 10 & 15 & 40 \\
\hline 6 & & & & 4 & 40 & 10 & 7 & 7 & 20 \\
\hline 7 & & & & 6 & 60 & $\mathbf{5}$ & 2 & 5 & 15 \\
\hline 8 & & & & 8 & 50 & 5 & 2 & 2 & 4 \\
\hline
\end{tabular}

* Irrigated after chlorate application only.

morning, and later in the day irrigated again with varying volumes of water, measured through a meter. The remaining four plots were sprayed without previous irrigation and then irrigated with measured volumes, corresponding to the second irrigation given the first four plots. The results appear in table 5 .

Considering first the preirrigated plots, it appears that 2 inches of water after the chlorate application did not carry the chemical deep enough and that the plants resprouted from below. On the other hand, 8 inches of water resulted in too great a dilution, so that plants were able to survive and resprout. But 4 and 6 inches carried the chemical to the critical depth and gave the best results. In the dry plots the water bearing the chlorate penetrated to a lesser depth, since it moistened the soil to its field capacity as it descended. Here the 8-inch application gave the best results, and the control of the weed was excellent.

Though the results of this experiment are promising, work in the greenhouse on numerous soils has indicated that the fixing of chlorate depends largely upon soil type. Further studies along this line have been delayed to await the greenhouse experiments, which are in progress. 


\section{Sodium Chlorate as a Translocated Spray}

Since, by using irrigation water, weeds could be treated through the soil with chlorate at almost any time of the year, it is desirable to determine the best season for the application. This should be known not only in relation to the seasonal effect upon chlorate decomposition in the soil, caused by differences in temperature, but also with respect to the various stages in the annual cycle of the plant. Spraying the living foliage of plants, on the other hand, always involves the complicating factor of rapid absorption and root killing by translocation of the toxic chemical within the plant. The mechanism responsible for this action has been fully described in connection with the use of acid arsenical sprays. ${ }^{(7,2,4)}$

Where plants in full blossom, growing in a moist soil, are sprayed during the day with a chlorate solution, little or none of the chemical is translocated into the roots, as shown in table 1 and by many tests in the field $^{(10)}$ and laboratory. When, on the other hand, all factors influencing rapid absorption and translocation are considered and the applications are made according to recommendations for the acid arsenicals, roots may be rapidly killed to depths of 3 feet or more. The results of plot tests presented in table 6 have been. selected to indicate the relative effects of night spraying, concentration of the solution, differences in soil moisture, and the use of acid upon translocation and root killing.

When plot 4 is compared with plot 3 , night spraying proves most effective. Plot 2 illustrates the effect of low concentration upon penetration of the spray solution. The inclusion of acid compensates not only for the low concentration but also for the difference between day and night spraying by shortening the time required for penetration of the solution. The temperature was high when these sprays were applied, and the acid solution began to discolor the leaves within 5 minutes after its application.

Finally, plot 8 shows the retarding effect of high soil moisture upon translocation. The results on plots 7 and 8 appear better than they really were, because of slower growth during the cooler period following the spraying. As the first rain in the fall of 1931 did not occur until October 22 , the effects shown in the first six plots are produced entirely by differences in movement of the chlorate within the plants. The roots in plots $4,5,6$, and 7 were dead to a depth of 2 feet or more within two weeks after spraying, and all resprouts were chlorotic, indicating sublethal amounts of chlorate at even greater depths.

\section{Relation of Stage of Growth to the Effects of Chlorate}

Keeping in mind this rapid action of chlorate under certain conditions and the two points previously mentioned, namely the seasonal effect 
upon chlorate decomposition and the relation of the growth cycle of the plant to effectiveness of sprays, a series of plots was treated to differentiate between application through the plant, through the soil, and a combination of both.

One group of three plots having mature plants and low soil moisture was treated on June 24, 1932. At the same time twelve other plots were hoed off clean and given a thorough irrigation. These were treated in

TABLE 6

The Effect of Time of Day, Acidity, Concentration, and Soil Moisture upon the Roo't Killing of Morning-Glory by Sodium Chlorate Sprays

\begin{tabular}{|c|c|c|c|c|c|c|c|}
\hline \multirow{2}{*}{$\begin{array}{l}\text { Plot } \\
\text { No }\end{array}$} & \multicolumn{2}{|c|}{ Spray solution } & \multicolumn{2}{|c|}{ Time of application } & \multirow{2}{*}{$\begin{array}{c}\text { Soil } \\
\text { moisture }\end{array}$} & \multicolumn{2}{|c|}{ Resprouting } \\
\hline & $\begin{array}{l}\mathrm{NaClO}_{3} \\
\text { per sq. rod, } \\
\text { in lbs. }\end{array}$ & $\begin{array}{c}\mathrm{H}_{2} \mathrm{SO}_{4} \\
\text { per sq. rod, } \\
\text { in lbs. }\end{array}$ & Date, 1931 & Hour & & Date, 1931 & $\begin{array}{c}\text { Estimated } \\
\text { per cent }\end{array}$ \\
\hline 1 & 1 & $\ldots \ldots$ & Aug. 20 & 4:00 p.m. & Low & Oct. 8 & 90 \\
\hline 2 & 1 & $\ldots \ldots \ldots$ & Aug. 20 & 7:00 p.m. & Low & Oct. 8 & 90 \\
\hline 3 & 3 & $\ldots \ldots .$. & Aug. 20 & 5:00 p.m. & Low & Oct. 8 & 80 \\
\hline 4 & 3 & ......... & Aug. 20 & 8:00 p.m. & Low & Oct. 8 & 10 \\
\hline 5 & 1 & $11 / 4$ & Aug. 22 & 4:00 p.m. & Low & Oct. 8 & 10 \\
\hline 6 & 1 & $11 / 4$ & Aug. 22 & 7:00 p.m. & Low & Oct. 8 & 10 \\
\hline 7 & 3 & $\ldots \ldots$ & Sept. 28 & 3:45 p.m. & Low & Nov.23 & 5 \\
\hline 8 & 3 & $\ldots \ldots \ldots$ & Sept. 28 & 3:15 p.m. & High & Nov.23 & 40 \\
\hline
\end{tabular}

groups of three at later periods (table 7) as follows: one plot of each group was simply sprayed with 3 pounds of sodium chlorate in 3 gallons of water; one plot was hoed off clean and a like application made to the bare soil, followed by one 6-inch irrigation on the following morning; the third plot was sprayed in the evening, as was the first, and then irrigated on the following morning like the second. The first plot was allowed to stand for the remainder of the season with no further treatment; the second and third were hoed to form a mulch after the top soil became dry so that conditions were optimum for regrowth of the plants.

By November 21, 1932, there had been only one light rain totaling 0.08 inch; the treatment on the first of each group of three plots may therefore be considered at that time to have been effective only through the plant. Treatment on the second of each group was through the soil alone, and the third plot in each represents a combination of treatment through the plant and through the soil.

In the treatments through the plants, the relation of maturity and soil moisture to absorption and translocation in the plant is clearly shown. Results on the second plot in each group of three, show that midsummer is the poorest time to make soil applications. Two factors are involved in this response. According to tables 2, 3, 4, and 5, plants may be ' $:$ :led by 


\begin{tabular}{|c|c|c|c|c|c|c|c|}
\hline 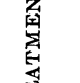 & 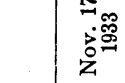 & 음 숭 & 8 요 & 889 & ద్లి జ ని & జ & 2 \\
\hline 虫 & 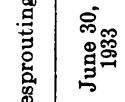 & مי & "ొ 80 & 891 & ำ 요 & 20 & n 음 \\
\hline 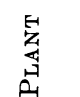 & 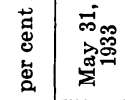 & 요 & 고 요 & 유 우 & ํㅗㅇำ & N & 용 \\
\hline 舅臂 & 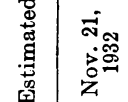 & 용요 & 옹ㅇㅇ 아 & 880 & ర్లి ద్ల ద & 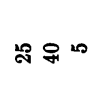 & 10 o \\
\hline 急蛋 & 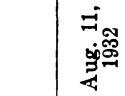 & రిల 8 & $8 ㅇ$ & 임 요 & 000 & $\vdots \quad \vdots \quad \vdots$ & $\vdots \vdots \vdots$ \\
\hline 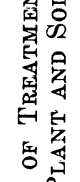 & 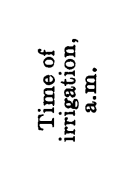 & 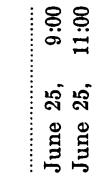 & 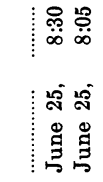 & 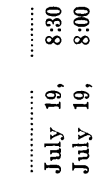 & 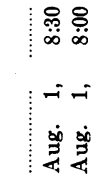 & 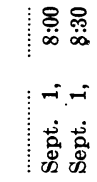 & 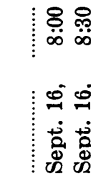 \\
\hline 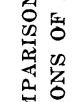 & 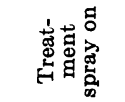 & 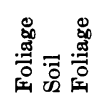 & 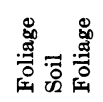 & 总 & 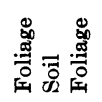 & 总 & 嘼 \\
\hline 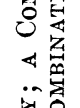 & 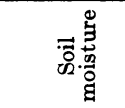 & 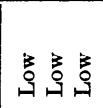 & 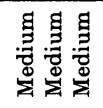 & 点点苟 & 点点点 & 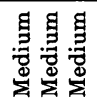 & 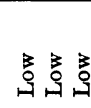 \\
\hline 考罢 & 毛 & $\underbrace{}_{\infty}$ & مْ & 穴号 & 官染 & 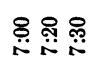 & 용 \\
\hline 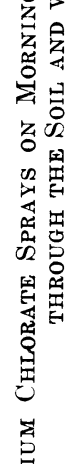 & 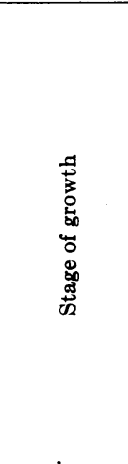 & 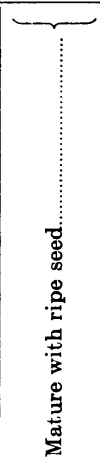 & 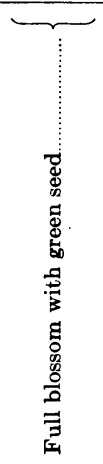 & 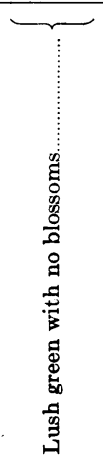 & 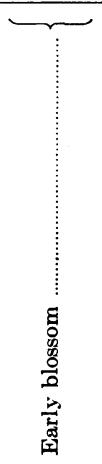 & 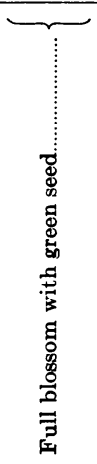 & 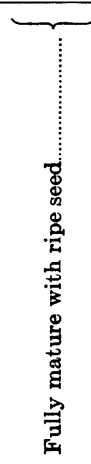 \\
\hline $\begin{array}{l}\text { ठ0 } \\
\text { कू } \\
\text { 동 } \\
\text { 연 }\end{array}$ & 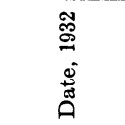 & 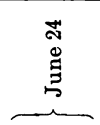 & 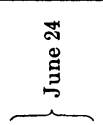 & 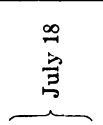 & $\begin{array}{c}\vec{m} \\
3 \\
3\end{array}$ & 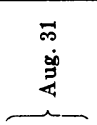 & 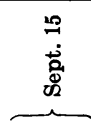 \\
\hline $\begin{array}{l}\text { 国 } \\
\text { 密 } \\
\text { 되 }\end{array}$ & $\stackrel{\overrightarrow{0}}{\vec{a}} \dot{0}$ & $-\infty \infty$ & O מ ה W & $-\infty \infty$ & 으 $=\cong$ & 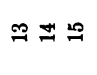 & $\stackrel{0}{\sim} \approx \stackrel{\infty}{\sim}$ \\
\hline
\end{tabular}


chlorate present in the soil during the period of spring vegetative activity. By June the roots are well stored with starch again, and the plants do not respond so well to chlorate treatment. In view of the results on November 17, 1933 (table 7) and the success of winter (tables 2, 3, and 4) and spring (table 5) applications, the effect of high soil temperature at the time of application on decomposition of the chlorate becomes apparent.

The outstanding feature of this experiment is the increased effectiveness where a combination treatment is given. When advantage is taken of all factors influencing treatment through the plant and through the soil, the effects are apparently additive and the results optimum. This type of treatment should form the basis for a successful field practice provided all conditions can be properly met. The results in November, 1933, represent practical control on plots 3,15 , and 18 .

\section{Effects of Pretreatments Upon the Results of Chlorate Applied Through the SoIL}

Since chlorate absorbed by plants apparently lowers their starch reserves, ${ }^{(8)}$ possibly a weakening of the roots of morning-glory by continued reduction or removal of top growth would render the plants more susceptible to killing by this chemical. A number of plots were treated during the summer of 1932 with this in mind. One group of three was hoed at weekly intervals for twelve times; a second group was sprayed five times with 2 per cent sodium chlorate solution, a third with $1 / 2$ per cent sodium arsenite, and a fourth with Diesel oil. Included in this experiment was a fifth group of seven plots sprayed with the acid arsenical in July. One of these plots received no further treatment; three of them received varying amounts of sodium chlorate on January 15, 1933. The remaining plots in the fifth group and all plots in other groups received varying applications of sodium chlorate on December 16. The results appearing the following season are recorded in table 8 .

When these figures are compared with those of table 3 , the only pretreatment at all beneficial appears to have been the acid arsenical spray. All others apparently inhibited the absorption of the chlorate or altered its distribution in the soil. The plots that had received chlorate sprays showed the cumulative effects of this extra chlorate; but all these pretreatments, though designed to weaken the plants, seemed to make them more resistant as far as winter treatment with chlorate was concerned. The acid arsenical treatment killed them to a depth of 3 feet or more, and they failed to recover. As the additional injury from chlorate was enough to keep them from coming through, this combination treatment was of practical value. Since the same effect may be obtained in the fall 


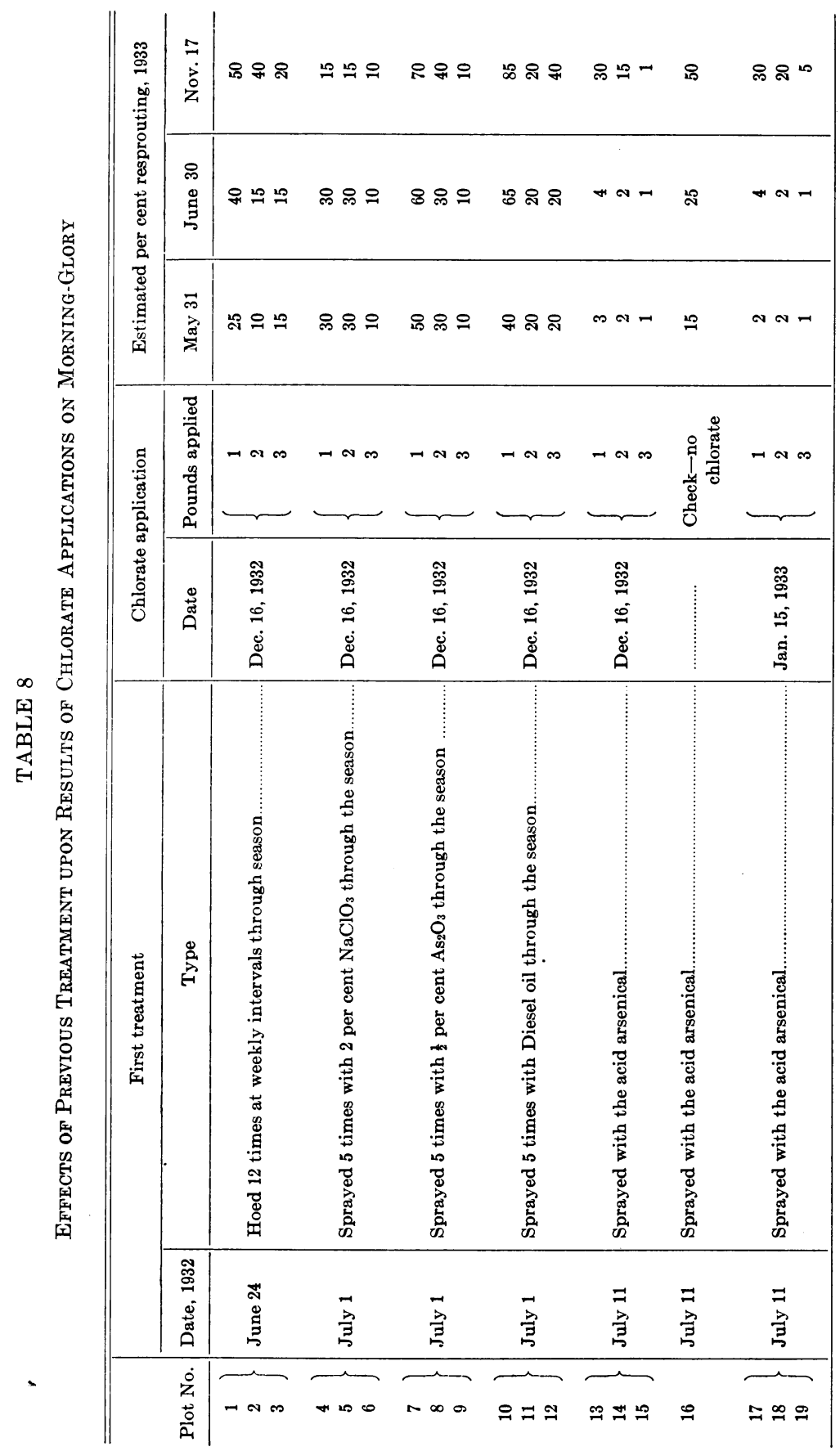


from one treatment of chlorate alone, apparently a separate acid arsenical spray would be justified only under special conditions.

\section{Effects of Various Application Methods Upon Results with Autumn Sprays}

A number of plots were treated during the fall of 1932 to compare simple spraying with spraying followed by water sprays, irrigation, and sulfuric acid, all with and without subsequent irrigation. In the series were included straight soil treatments on hoed plots and a number of divided applications in which the chlorate dosage was put on in two and three separate applications. The results appear in table 9.

In interpreting the results of these tests, one should remember that the winter rains started in November. Any differences caused by the variations in treatment were therefore soon overshadowed by the results of absorption from the soil. The total season's rainfall, furthermore, was only 9.56 inches, so that the additional 6 inches applied to many of these plots probably did little more than compensate for the evaporation occurring during the six-month period of rainfall. All these plots fell, therefore, within the 8-to-12-inch requirement indicated in tables 2, 3, and 4 , as necessary for proper distribution of the chemical.

In general better results were secured on the irrigated plots than on the unirrigated. Spraying with water or sulfuric acid on the morning after the chlorate application seemed to have no significant effect at this time of year. Irrigation immediately after spraying reduced the effectiveness considerably, as shown by plot 8 . This same effect was noted in the early summer on similarly treated plots and on plots receiving the dry salt and immediate irrigation.

Dividing the application, aiming at a more uniform distribution of the chemical in the soil, had no significant effect. Apparently any treatment by which the tops of the plants are killed and the chlorate is subsequently leached to a proper depth in the soil gives excellent results at this time of the year.

An additional series of plots was treated during December, January, and February, making 1 and 2-pound applications at different intervals, each plot receiving a total of 3 pounds per square rod. There was no difference in these results, either, except where the bulk of the chemical was applied so late as to receive insufficient rain for proper leaching.

\section{Cutting as a Final Treatment for Chlorate-Injured Plants}

Two further experiments are of practical significance in the use of sodium chlorate. When the plants on the plots reported in table 5 were about 6 weeks old, they were very chlorotic and had practically stopped 
TABLE 9

Fall Treatment; a Comparison of Various Methods of Applying SODIUM CHLORATE ON MORNING-GLORY

\begin{tabular}{|c|c|c|c|c|c|c|c|c|}
\hline \multirow[b]{2}{*}{$\begin{array}{l}\text { Plot } \\
\text { No. }\end{array}$} & \multicolumn{4}{|c|}{ Treatment } & \multicolumn{4}{|c|}{ Estimated per cent resprouting } \\
\hline & No. & $\begin{array}{l}\text { Date, } \\
1932\end{array}$ & Time & Type & $\begin{array}{c}\text { Nov. } 21 \\
1932\end{array}$ & $\underset{1933}{\operatorname{May} 31}$ & $\begin{array}{c}\text { June } 30 \\
1933\end{array}$ & $\begin{array}{c}\text { Nov. } 17 \\
1933\end{array}$ \\
\hline 1 & 1 & Oct. 21 & 9:15 p.m. & Sprayed 3 lbs................... & $\mathbf{0}$ & 1 & 1 & 5 \\
\hline 2 & 1 & Oct. 25 & 8:00 p.m. & Sprayed 3 lbs.................... & 0 & 3 & 5 & 10 \\
\hline 3 & $\begin{array}{l}1 \\
2\end{array}$ & $\begin{array}{ll}\text { Oct. } & 21 \\
\text { Oct. } & 22\end{array}$ & $\begin{array}{l}\text { 9:00 p.m. } \\
\text { 8:00 a.m. }\end{array}$ & 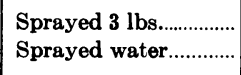 & $\mathbf{0}$ & 1 & 1 & 5 \\
\hline 4 & $\begin{array}{l}1 \\
2\end{array}$ & $\begin{array}{l}\text { Oct. } 25 \\
\text { Oct. } 26\end{array}$ & $\begin{array}{l}\text { 8:30 p.m. } \\
\text { 8:15 a.m. }\end{array}$ & $\begin{array}{l}\text { Sprayed } 3 \text { lbs...................................... } \\
\text { Sprayed water }\end{array}$ & $\mathbf{0}$ & 7 & 5 & 10 \\
\hline 5 & $\begin{array}{l}1 \\
2 \\
3\end{array}$ & $\begin{array}{ll}\text { Oct. } & 21 \\
\text { Oct. } & 22 \\
\text { Oct. } & 22\end{array}$ & $\begin{array}{l}\text { 8:00 p.m. } \\
\text { 8:15 a.m. } \\
\text { 1:00 p.m. }\end{array}$ & 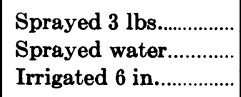 & 0 & 2 & 2 & 5 \\
\hline 6 & $\begin{array}{l}1 \\
2 \\
3\end{array}$ & $\begin{array}{ll}\text { Oct. } & 21 \\
\text { Oct. } & 22 \\
\text { Oct. } & 22\end{array}$ & $\begin{array}{l}\text { 8:45 p.m. } \\
\text { 8:30 a.m. } \\
\text { 2:00 p.m. }\end{array}$ & 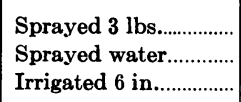 & 0 & 0 & 0 & 1 \\
\hline 7 & $\begin{array}{l}1 \\
2\end{array}$ & $\begin{array}{l}\text { Oct. } 22 \\
\text { Oct. } 25\end{array}$ & $\begin{array}{l}\text { 9:00 a.m. } \\
\text { 1:00 p.m. }\end{array}$ & 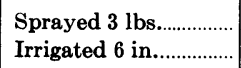 & $\mathbf{0}$ & 0 & 1 & 3 \\
\hline 8 & $\begin{array}{l}1 \\
2 \\
3\end{array}$ & $\begin{array}{ll}\text { Oct. } & 22 \\
\text { Oct. } & 22 \\
\text { Oct. } & 24\end{array}$ & $\begin{array}{l}\text { 10:00 a.m. } \\
\text { 10:15 a.m. } \\
\text { 1:00 p.m. }\end{array}$ & $\begin{array}{l}\text { Sprayed } 3 \text { lbs............... } \\
\text { Irrigated } 3 \text { in............. } \\
\text { Irrigated } 3 \text { in............... }\end{array}$ & 0 & 60 & 50 & 20 \\
\hline 9 & $\begin{array}{l}1 \\
2 \\
3\end{array}$ & $\begin{array}{ll}\text { Oct. } 25 \\
\text { Oct. } 25 \\
\text { Oct. } 26\end{array}$ & $\begin{array}{l}\text { 8:15 p.m. } \\
\text { 9:15 p.m. } \\
\text { 8:00 a.m. }\end{array}$ & \begin{tabular}{|l} 
Sprayed $3 \mathrm{lbs} . \ldots \ldots \ldots . .$. \\
Sprayed $\mathrm{H}_{2} \mathrm{SO}_{4} \ldots \ldots \ldots . .$. \\
Sprayed water.............
\end{tabular} & 0 & 2 & 3 & 7 \\
\hline 10 & $\begin{array}{l}1 \\
2 \\
3\end{array}$ & $\begin{array}{ll}\text { Oct. } & 21 \\
\text { Oct. } & 21 \\
\text { Oct. } & 22\end{array}$ & $\begin{array}{l}\text { 8:50 p.m. } \\
\text { 10:00 p.m. } \\
\text { 3:00 p.m. }\end{array}$ & 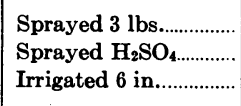 & 0 & 1 & 1 & 1 \\
\hline 11 & $\begin{array}{l}1 \\
2 \\
3\end{array}$ & $\begin{array}{l}\text { Oct. } 24 \\
\text { Oct. } 25 \\
\end{array}$ & $\begin{array}{l}\text { 2:00 p.m. } \\
8: 45 \text { p.m. }\end{array}$ & 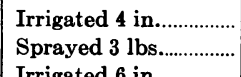 & 0 & 10 & 10 & 7 \\
\hline 12 & $\begin{array}{l}1 \\
2\end{array}$ & $\begin{array}{ll}\text { Oct. } & 24 \\
\text { Oct. } & 24\end{array}$ & $\begin{array}{l}\text { 10:00 a.m. } \\
\text { 10:30 a.m. }\end{array}$ & 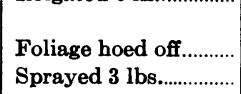 & 0 & 2 & 1 & 2 \\
\hline & $\begin{array}{l}3 \\
1\end{array}$ & $\begin{array}{l}\text { Oct. } 25 \\
\text { Oct. } 24\end{array}$ & $\begin{array}{l}\text { 1:30 p.m. } \\
\text { 9:00 a.m. }\end{array}$ & $\begin{array}{l}\text { Irrigated } 6 \text { in } \\
\text { Foliage hoed off............................ }\end{array}$ & & & & \\
\hline 13 & $\begin{array}{l}2 \\
3 \\
4\end{array}$ & $\begin{array}{l}\text { Oct. } 24 \\
\text { Oct. } 24 \\
\text { Oct. } 25\end{array}$ & $\begin{array}{l}\text { 9:30 a.m. } \\
\text { 11:00 a.m. } \\
\text { 11:00 a.m. }\end{array}$ & $\begin{array}{l}\text { Irrigated } 4 \text { in................. } \\
\text { Sprayed } 3 \text { lbs............. } \\
\text { Irrigated } 6 \text { in............... }\end{array}$ & 6 & 2 & 1 & 2 \\
\hline & $\begin{array}{l}1 \\
2 \\
3\end{array}$ & $\begin{array}{ll}\text { Oct. } & 21 \\
\text { Oct. } & 22 \\
\text { Oct. } 22\end{array}$ & $\begin{array}{l}\text { 8:15 p.m. } \\
\text { 9:30 a.m. } \\
\text { 1:30 p.m. }\end{array}$ & 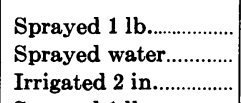 & & & & \\
\hline 14 & $\begin{array}{l}4 \\
5 \\
6 \\
7\end{array}$ & $\begin{array}{lr}\text { Oct. } & 29 \\
\text { Oct. } & 29 \\
\text { Nov. } & 5 \\
\text { Nov. } & 5\end{array}$ & 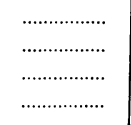 & 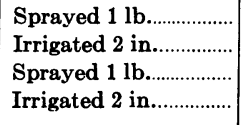 & 0 & 15 & 10 & 5 \\
\hline
\end{tabular}


TABLE 9 (continued)

\begin{tabular}{|c|c|c|c|c|c|c|c|c|}
\hline \multirow{2}{*}{$\begin{array}{l}\text { Plot } \\
\text { No. }\end{array}$} & \multicolumn{4}{|c|}{ Treatment } & \multicolumn{4}{|c|}{ Estimated per cent resprouting } \\
\hline & No. & $\begin{array}{l}\text { Date, } \\
1932\end{array}$ & Time & Type & $\underset{1932}{\text { Nov. }_{2} 21}$ & $\underset{1933}{\text { May } 31}$ & $\begin{array}{c}\text { June } 30 \\
1933\end{array}$ & $\underset{1933}{\text { Nov. } 17}$ \\
\hline 15 & $\begin{array}{l}1 \\
2 \\
3 \\
4 \\
5 \\
5 \\
6\end{array}$ & $\begin{array}{lr}\text { Oct. } & 25 \\
\text { Oct. } 25 \\
\text { Nov. } 8 \\
\text { Nov. } 8 \\
\text { Nov. } 22 \\
\text { Nov. } 22\end{array}$ & \begin{tabular}{c} 
9:00 a.m. \\
9:15 a.m. \\
$\ldots \ldots \ldots \ldots \ldots \ldots . .$. \\
\hdashline$\ldots \ldots \ldots \ldots . . . .$. \\
$\ldots \ldots \ldots \ldots \ldots . . . .$.
\end{tabular} & 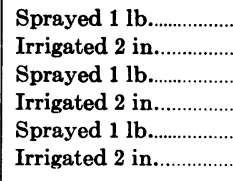 & 0 & 7 & 5 & 5 \\
\hline 16 & $\begin{array}{l}1 \\
2 \\
3 \\
4 \\
5\end{array}$ & $\begin{array}{l}\text { Oct. } 21 \\
\text { Oct. } 22 \\
\text { Oct. } 22 \\
\text { Oct. } 29 \\
\text { Oct. } 29\end{array}$ & $\begin{array}{l}\text { 8:30 p.m. } \\
\text { 9:15 a.m. } \\
\text { 2:30 p.m. } \\
\ldots \ldots \ldots \ldots \ldots . . . \\
\ldots \ldots \ldots \ldots \ldots . . .\end{array}$ & 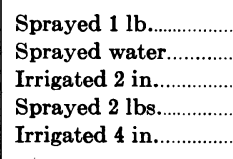 & 0 & 3 & 3 & 4 \\
\hline 17 & $\begin{array}{l}1 \\
2 \\
3 \\
4 \\
5\end{array}$ & $\begin{array}{lr}\text { Oct. } & 21 \\
\text { Oct. } & 22 \\
\text { Oct. } & 22 \\
\text { Nov. } & 4 \\
\text { Nov. } & 4\end{array}$ & $\begin{array}{l}\text { 8:40 p.m. } \\
\text { 8:45 a.m. } \\
\text { 3:30 p.m. } \\
\ldots \ldots \ldots \ldots . . . \\
\ldots \ldots \ldots . . . .\end{array}$ & 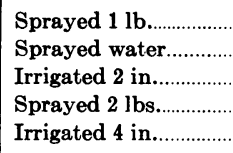 & 0 & 1 & 1 & 4 \\
\hline 18 & $\begin{array}{l}1 \\
2 \\
3 \\
4 \\
5 \\
6 \\
7\end{array}$ & $\begin{array}{lr}\text { Oct. } & 25 \\
\text { Oct. } & 25 \\
\text { Oct. } & 25 \\
\text { Nov. } & 1 \\
\text { Nov. } & 1 \\
\text { Nov. } & 8 \\
\text { Nov. } & 8\end{array}$ & $\begin{array}{l}\text { 8:00 a.m. } \\
8: 3 \text { a.m. } \\
8: 45 \text { a.m. } \\
\cdots \cdots \cdots \cdots \cdots . . . \\
\cdots \cdots \cdots \cdots \cdots . . . \\
\cdots \cdots \cdots \cdots \cdots . . . \\
\cdots \cdots \cdots \cdots . . .\end{array}$ & 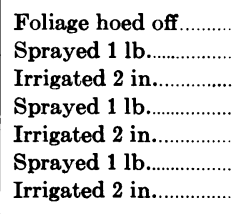 & 0 & 5 & 5 & 5 \\
\hline 19 & $\begin{array}{l}1 \\
2 \\
3 \\
4 \\
5\end{array}$ & $\begin{array}{l}\text { Oct. } 24 \\
\text { Oct. } 24 \\
\text { Oct. } 24 \\
\text { Oct. } 31 \\
\text { Oct. } 31\end{array}$ & $\begin{array}{l}\text { 8:00 a.m. } \\
\text { 8:30 a.m. } \\
\text { 3:30 p.m. } \\
\ldots \ldots \ldots \ldots . . . . \\
\ldots \ldots \ldots . . . .\end{array}$ & 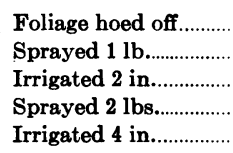 & 0 & 7 & 5 & 3 \\
\hline 20 & $\begin{array}{l}1 \\
2 \\
3 \\
4 \\
5\end{array}$ & \begin{tabular}{lr|} 
Oct. & 24 \\
Oct. & 24 \\
Oct. & 24 \\
Nov. & 6 \\
Nov. & 6
\end{tabular} & \begin{tabular}{l} 
2:30 p.m. \\
3:00 p.m. \\
4:00 p.m. \\
$\ldots \ldots \ldots . . . .$. \\
\hdashline$\ldots \ldots . .$.
\end{tabular} & $\begin{array}{l}\text { Foliage hoed off.......... } \\
\text { Sprayed } 1 \mathrm{lb} . . . . . . . . . . . \\
\text { Irrigated } 2 \text { in............. } \\
\text { Sprayed } 2 \text { lbs............ } \\
\text { Irrigated } 4 \text { in............. }\end{array}$ & 0 & 15 & 5 & 5 \\
\hline
\end{tabular}

growing. As further injury might have weakened them even more, onehalf of each plot was hoed about July 10 and again late in August. The results in table 5 are all for the unhoed portions. Table 10 gives the data for both hoed and unhoed plots.

The differences shown here are outstanding, especially on the plots where the degree of control was already high. According to common experience with sodium chlorate, a fairly satisfactory control may be obtained with a moderate application, but a much greater amount is required for complete eradication. Judging from these results, a few weed cuttings during the summer and fall after a spring application or during the summer after a winter application may go a long way toward 
completing the work. The plants must be severely weakened, however, before this practice will give the desired results. Further tests on this method carried out in 1933 emphasize that only weak plants are affected by the treatment.

\section{Leaching to Rid the Land of Chlorate}

The other point to be considered is the ridding of the land of residual chlorate after the weeds have been killed. Morning-glory in a field at Davis had been sprayed in the fall of 1930 with sodium chlorate. Figure

TABLE 10

Results of Hoeing Plots Seriously Affected by Chlorate

\begin{tabular}{|c|c|c|c|c|c|c|c|c|c|c|c|c|c|}
\hline \multirow{3}{*}{$\begin{array}{l}\text { Plot } \\
\text { No. }\end{array}$} & \multicolumn{3}{|c|}{ Treatment } & \multicolumn{10}{|c|}{ Estimated per cent resprouting (1933) } \\
\hline & \multirow{2}{*}{$\begin{array}{l}\text { Preirri- } \\
\text { gation, } \\
\text { inches }\end{array}$} & \multirow[b]{2}{*}{$\begin{array}{c}\mathrm{NaClO}_{3}, \\
\text { lbs. }\end{array}$} & \multirow{2}{*}{$\begin{array}{l}\text { Irri- } \\
\text { gation, } \\
\text { inches }\end{array}$} & \multicolumn{2}{|c|}{ March 23} & \multicolumn{2}{|c|}{ May 31} & \multicolumn{2}{|c|}{ June 30} & \multicolumn{2}{|c|}{ Aug. 12} & \multicolumn{2}{|c|}{. Nov. 17} \\
\hline & & & & $\begin{array}{l}\text { Un- } \\
\text { hoed }\end{array}$ & Hoed & $\begin{array}{l}\text { Un- } \\
\text { hoed }\end{array}$ & Hoed & $\begin{array}{l}\text { Un- } \\
\text { hoed }\end{array}$ & Hoed & $\begin{array}{l}\text { Un- } \\
\text { hoed }\end{array}$ & Hoed & $\begin{array}{c}\text { Un- } \\
\text { hoed }\end{array}$ & Hoed \\
\hline 1 & ) & & 2 & 1 & 0 & 10 & 2 & 10 & 2 & 15 & 5 & 50 & 7 \\
\hline 2 & 4 & 3 & 4 & 0 & 0 & 1 & 1 & 1 & 1 & 5 & 2 & 10 & 1 \\
\hline 3 & & & 6 & 1 & 0 & 5 & 2 & 10 & 5 & 15 & 5 & 15 & 5 \\
\hline 4 & & & 8 & 5 & 0 & 30 & 5 & 30 & 5 & 50 & 7 & 50 & 7 \\
\hline 5 & & & 2 & 10 & 0 & 10 & 7 & 15 & 10 & 20 & 7 & 40 & 7 \\
\hline 6 & $\ldots$ & 3 & 4 & 5 & 0 & 7 & 3 & 7 & 3 & 15 & 0 & 20 & 1 \\
\hline 7 & & & 6 & 2 & 0 & 2 & 0 & 5 & 0 & 15 & 0 & 15 & 0 \\
\hline 8 & & & 8 & 2 & 0 & 2 & 0 & 2 & 0 & 5 & 0 & 4 & 1 \\
\hline
\end{tabular}

18 of the companion paper of this issue ${ }^{(3)}$ illustrates the sterile condition that existed. A total of about one acre was involved; and various treatments, including applications of ammonium sulfate, sulfur, and manure had been tried during the previous winter with no effect upon the sterility.

The tests that were run on the soil from these areas are described in the paper which follows. ${ }^{(3)}$ It suffices here to state that chlorate was present to a depth of 20 inches, with the highest concentration in the 4 to 8 -inch level. Although 30 inches of rain had fallen since this chlorate was applied, little effective leaching had taken place. Rainfall, because of its intermittent nature, is less effective than water continuously applied as in irrigation. High soil temperatures, occurring only after considerable drying, also were ineffective in decomposing the chlorate.

After these tests the field was leached free of chlorate and later planted to alfalfa. The details of the process are given elsewhere. ${ }^{(3)}$ The leaching was entirely satisfactory and the alfalfa made normal growth through the first season. Leaching is apparently the most satisfactory method of ridding the land of chlorate where water is available. 


\section{DISCUSSION}

Judging from experiments described in this paper, as well as field experience and a thorough review and interpretation of the literature, sodium chlorate may kill deep-rooted perennial plants by two separate and distinct types of action. These are (1) rapid absorption by the foliage and translocation to the roots through the vascular system of the plant and (2) absorption of the chemical from the soil by the roots. From a consideration of the mechanism involved and experience in the use of acid arsenical sprays, success by means of the first method alone seems limited by a very special set of requirements, often difficult to realize in the field.

The experimental results of Åslander, ${ }^{(1)}$ Muenscher, ${ }^{(11)}$ and the writer, together with the generally successful use of chlorates in the field by workers in regions of summer rains, show that the soil-application method is the more practical. Ideal conditions for this method, however, may not be readily found; and experiments reported in table 7 indicate that under certain conditions a combination of the two actions may give more favorable results than either alone. Evidently such a combined action often takes place where summer spraying is practiced in humid climates and largely accounts for the confusion in interpretation that occurs in the literature. Hulbert, Bristol, and Benjamin ${ }^{(6)}$ have emphasized the necessity of giving plot tests full time for action through the soil to reach completion, before passing judgment on the effectiveness of a given treatment. When the relative values of these two actions are fully appreciated, the many conflicting ideas that one finds in print concerning spray practice should be replaced by more rational recommendations.

According to Loomis and his colleagues, ${ }^{(10)}$ "... . sodium chlorate dissolved in the soil water readily penetrates and kills the roots and rhizomes of either active or dormant plants." If this were true, with no reservations, all that would be necessary in killing deep-rooted weeds would be to expose the roots to chlorate in the soil moisture. The results of our winter applications might indicate that such treatment is successful.

But, although the roots may show some internal injury, movement of chlorate through the soil during the winter, as in plots 3 and 4 , table 2, or in the spring, as in plot 4, table 5, was not sufficient to kill them. Loomis, et al. ${ }^{(10)}$ cite a similar instance in the spring of 1931 when an application of 600 pounds per acre of sodium chlorate, followed by $1 \frac{1 / 2}{2}$ inches of rain within 48 hours, failed to kill quack grass, although the subsoil contained toxic quantities of the chlorate. Evidently time enters 
the problem, and the relative rates of chlorate movement and absorption are of vital importance. The rapid killing of many weeds after summer spraying and leaching by rains, compared with the slow killing of roots during the winter, as shown by many cases of heavy resprouting in the spring, followed by slow decline and death during the summer, indicates that dormant roots absorb chlorate from the soil at a slower rate than actively growing ones.

The many recommendations for early summer spraying that have come from eastern states, together with the results of the experiments cited in table 7, indicate that treatment later in the summer is also less effective. Though the temperature effect on chlorate decomposition is partly responsible for this, roots fully stored with starch are probably less susceptible to chlorate injury; for starch storage has been found to be a factor in the difference in susceptibility of various weed species. The evidence therefore seems to point to the spring season, from break of dormancy to the end of the vegetative period, as the optimum time for the effective absorption of chlorate from the soil.

The plot work presented in this paper indicates three possible methods for treating deep-rooted plants under California conditions.

1. Fall treatment, in which a certain amount of killing due to rapid absorption and translocation in the plant is followed by leaching and root absorption during the winter, spring, and summer. If this treatment is used in October, November, or early December, night spraying is unnecessary except in exceedingly dry spells. Optimum results however, will follow the close observance of all factors favoring absorption and movement through the plants. Fall rains of sufficient quantity to cause a flush of vegetative activity will practically nullify this effect through the plant.

2. Winter treatment, in which all absorption takes place from the soil. In this method the relation of soil type and rainfall to vertical distribution of the chlorate is of paramount importance. These points are receiving further study, but data presented indicate that the chemical must be present throughout the top 4-6 feet of soil in such a concentration as to become lethal at some time during the year. Too great dilution or a restricted distribution will limit the effectiveness of the treatment.

3. Spring application, followed by measured irrigation. This method simulates the condition encountered in regions of summer rains. Though it has not yet received extensive trial, it should give excellent results where carefully used. Here, again, soil type will largely determine the amount of water needed; and only where the relation of soil type to fixing of chlorate has been tested can the method be used with any assurance of success. Where flooding is used, the land must be level, to 
insure uniformity in depth of moisture penetration. Sprinkling should give the best results if sufficient water is applied at a slow rate.

Differences in species susceptibility determine to a large extent the dosages to be recommended in using chlorates. ${ }^{(5,6,11)}$ Judging from experience in California, Russian knapweed, Canada thistle, and willows are among the easily controlled species; morning-glory, white horse nettle, Johnson grass, and Bermuda grass are more difficult; and hoary cress, camel's thorn, and nut grass require excessive amounts of chemical. These variations, as found in the field, depend upon differences in root permeability, ${ }^{(12,13)}$ food reserves, root patterns, general growth habits, and ecologic factors determining species distributions, and are too complex for anything but empirical determination. Much of this work has already been done. ${ }^{(6)}$

Attempts at a more uniform distribution of chlorate in the soil by division of the dosage have not been effective, but in years of heavier rainfall or in soils with lower moisture-holding capacity such a procedure would probably insure against undue loss of chemical. Additional studies will be made on this phase of the problem as results of the soils work are obtained.

By hoeing off plants that had been severely injured by chlorate absorbed from the soil, the effectiveness of the treatment was increased. This practice is simple and inexpensive and should always be feasible.

Residual effects from chlorate applications are very common in regions of low summer rainfall. This, another problem involving the effect of soil type on chlorate behavior, will be treated further at a later date. If, however, irrigation water is not available for leaching, chlorates should be used with great discretion on lands where a rapid return to agricultural use is desired.

\section{SUMMARY}

Chlorates may kill deep-rooted perennial weeds $(a)$ by rapid absorption and translocation within the plant and $(b)$ by absorption from the soil by the roots. Experiments carried out in California serve to establish the relative importance of these two methods.

Daytime spraying of the foliage of greenhouse plants in blossom, with ample soil moisture, differed little from simple removal of tops by cutting.

Applying the same amount of chlorate to the soil killed morningglory and Russian knapweed but only injured hoary cress.

Plot experiments carried on through three winters in California show that proper vertical distribution of chlorate within the soil by leaching of winter rains is essential to success with the soil-treatment method. 
A similar vertical distribution may be accomplished by leaching with irrigation water.

Rapid absorption and translocation of chlorate through plants are conditioned by the same factors that control the action of acid arsenical spray.

Experiments designed to kill plants by chlorate action $(a)$ through the plant, $(b)$ through the soil, and $(c)$ through both the plant and the soil, indicate that the third method is the most effective.

Pretreatments aimed at a weakening of plants decreased rather than increased the effects of chlorate. The acid arsenical treatment in July, however, followed by chlorate in December, was very effective. The July treatment killed the roots to a depth of 3 feet or more.

Fall sprays, applied in a number of ways, were all effective against morning-glory. The only type of fall treatment that failed was a spray followed immediately by irrigation that washed the chlorate into the soil, leaving the foliage intact. A number of experiments of this nature proved ineffective.

Division of the dose into two and three separate applications proved of no additional benefit in these experiments, either in the fall or winter treatments. In winters of high rainfall this method might avoid excessive loss.

Winter treatments were effective as long as the bulk of the chlorate was applied early enough to be leached well into the soil. Late applications failed.

Hoeing of plants severely injured by chlorate absorbed from the soil weakened them and proved a practical means of increasing the effects of a given treatment.

Continuous leaching with irrigation water proved the best means of ridding the land of residual chlorate. Sterile areas leached with 36 inches of water were returned to use within a season by this practice. 
${ }^{1}$ Asllander, Alfred.

\section{LITERATURE CITED}

1928. Experiments on the eradication of Canada thistle, Cirsium arvense, with chlorates and other herbicides. Jour. Agr. Research 36:915-934. Illus.

" CRAFTS, A. S.

1933. The use of arsenical compounds in the control of deep-rooted perennial weeds. Hilgardia 7(9):361-372.

${ }^{3}$ CRAFTs, A. S.

1935. The toxicity of sodium arsenite and sodium chlorate in four California soils. Hilgardia $9(9): 459-498$.

"Crafts, A. S., and P. B. KenNedy.

1930. The physiology of Convolvulus arvensis (morning-glory or bindweed) in relation to its control by chemical sprays. Plant Physiol. 3:329-344.

${ }^{5}$ Fron, M., and R. Bertrand.

1934. Contribution à l'études de l'influence des chlorates sur la vegetation. Ann. Agron. [Paris] 4:1-25.

${ }^{6}$ Hulbert, H. W., R. S. Bristol, and L. V. Benjamin.

1931. Methods affecting the efficiency of chlorate weed killers. Idaho Agr. Exp. Sta. Bul. 189:1-12.

${ }^{7}$ Kennedy, P. B., and A. S. CRAFrTs.

1927. The application of physiological methods to weed control. Plant Physiol. 2:503-506.

${ }^{8}$ Latshaw, W. L., and J. W. Zahnley.

1927. Experiments with sodium chlorate and other chemicals as herbicides for field bindweed. Jour. Agr. Research $35: 757-767$.

${ }^{9}$ Loomis, W. E., Russell Bissey, and E. V. Smith.

1931. Chlorates as herbicides. Science 74(1924): 485 .

${ }^{10}$ Loomis, W. E., E. V. Smith, Russerl Bissey, and L. E. Arnold.

1933. The absorption and movement of sodium chlorate when used as an herbicide. Jour. Amer. Soc. Agron. 25:724-739.

${ }^{11}$ Muenscher, W. C.

1932. Killing perennial weeds with chlorates during winter. New York (Cornell) Agr. Exp. Sta. Bul. 542:1-8.

${ }^{12}$ Yamasaki, M.

1929. On the variation of rice varieties in the resistance to the toxic action of potassium chlorate, and its practical significance. Jour. Imp. Agr. Exp. Sta. Tokyo 1(1):1-24. (Summary in English.) Illus.

${ }^{13}$ YAMASAKI, M.

1929. The variation and correlation among varieties of wheat and barley in regard to the resistance to the toxic action of potassium chlorate. Jour. Imp. Agr. Exp. Sta. Tokyo 1(2):139-162. (Summary in English.) Illus. 